\title{
UNUSUAL FORMS OF ACHALASIA CARDIA AND ASSOCIATED NEUROMUSCULAR DISORDERS OF THE OESOPHAGUS
}

\author{
A. T. S. PaUl, F.R.C.S.(I), F.R.C.S.(E), F.R.C.S.(Eng.). \\ Thoracic Surgeon, General Hospital, Colombo, Ceylon \\ G. D. S. Pallawela, M.B.B.S.(Ceylon). \\ Registrar, Thoracic Unit-I, Colombo, Ceylon
}

NEUROMUSCULAR disorders of the lower œsophagus have been described under a variety of clinical names, some commonplace and others less well known. It is essential to have a clear concept of the disease we are dealing with, because in none of these can a specific organic cause be demonstrated. Indeed, it is the absence of an obvious organic lesion that is the most important factor in the definition of this syndrome.

Achalasia cardia is the term we use in preference to the word Cardiospasm as first used by Von Mikulicz (1882). In this condition there is a functional derangement of the mechanism of swallowing confined to the lower portion of the œsophagus where no obvious mechanical cause can be demonstrated by endoscopy. The term 'Cardiospasm' as used by Von Mikulicz rather tends to convey the impression of a spastic segment as being the major cause of the obstruction. On the contrary spasm is not a prominent feature of classical achalasia cardia, which can be demonstrated both by endoscopy and pressure manometry.

At this point we must divert our minds to the study of peristaltic waves and intraluminal pressure changes that occur in a normal œsophagus during the act of swallowing. Primary peristaltic waves initiated by the act of swallowing are followed by secondary peristaltic waves, due to mechanical distention of the esophagus by the bolus of food. These waves pass downwards to the region of the physiological sphincter at the lower reaches of the œsophagus where there is normally a state of increased tone, but not actually amounting to spasm. Under normal conditions this zone relaxes when the peristaltic waves reach it (Ingelfinger, 1960).

In achalasia, peristaltic waves are present in the lower œsophagus but they are of lesser amplitude than normal, and are not followed by a decrease in tone of the lower ' $p$ hysiological sphincter'. There is no 'spasm' as implied by the term cardiospasm Hence our preference for the use of the term $\vec{E}$ achalasia cardia.

In contrast to this we have the condition ofo diffuse spasm of the œsophagus, sometimes called the corkscrew œsophagus, pseudo-diverticulosis $\infty \rho$ functional diverticula, segmental spasm, curling of̊ the oesophagus (Moersch and Campbell, 1934). In this condition there is an increase of repetites and prolonged contractions often of great ampditude in the lower esophagus. This may associated with poor relaxation of the infer音? sphincter (Ellis, Code and Olsen, 1960).

Next in the group of neuromuscular disorders is the condition described as 'Hypertensive gastro œsophageal sphincter' by American author\$ (Code, Schlegal, Kelly, Jr., Olsen and Ellis, Jr.产 1960). In this condition the main feature is an excessive pressure in the region of the inferioe sphincter as detected by balloon transducers which? may amount to over $140 \mathrm{~cm}$. of water. Motility in the body of the œsophagus was normal in some cases but in the majority showed the generas picture of diffuse spasm.

Lastly, we have the condition of megacesophagus which is characterized by a gross dilatation of the œsophagus extending in most cases up to the pharynx, and associated with hypomotility and stagnation of the œsophageal contents.

Taken as a group, these diseases have severab things in common. Functionally they all cause. some derangement of the function of swallowing which can be demonstrated as a hold-up of opaque media on radiological examination in the loweru œsophagus. In all the rhythm of œsophageat motility is disordered and disorganized, in some cases amounting to virtual suppression and ir others manifest by violent exacerbations. In all o them the only organic lesion that could be demonstrated is the occasional diminution of 
TABLE I

Summary of Details of 32 Cases

\begin{tabular}{|c|c|c|c|c|c|c|c|c|c|c|}
\hline & Achalasia & $\begin{array}{l}\text { Mega- } \\
\text { œsopha- } \\
\text { gus }\end{array}$ & $\begin{array}{l}\text { Diffuse } \\
\text { Spasm }\end{array}$ & \begin{tabular}{|c|} 
Hypertro- \\
phic \\
Gastro- \\
œsophageal \\
Sphincter
\end{tabular} & $\begin{array}{c}\text { Dilata- } \\
\text { tion }\end{array}$ & $\begin{array}{c}\text { Heller's } \\
\text { Opera- } \\
\text { tion }\end{array}$ & $\begin{array}{l}\text { Pharyngo- } \\
\text { jejunos- } \\
\text { tomy }\end{array}$ & Cured & Deaths & $\begin{array}{c}\text { Refused } \\
\text { Surgical } \\
\text { Treat- } \\
\text { ment }\end{array}$ \\
\hline Male & 9 & 5 & 2 & - & I & II & I & 12 & $\mathbf{I}$ & 3 \\
\hline Female & 10 & 3 & I & 2 & 2 & II & - & 13 & - & 2 \\
\hline Total & 19 & 8 & 3 & 2 & 3 & 22 & I & 25 & I & 5 \\
\hline
\end{tabular}

Auerbach's plexus in the submucosa. Finally in all these apparently diverse clinical conditions the same treatment is successful whether we are dealing with the sluggish motility of a typical achalasia, the hypermotility of a diffuse œsophageal spasm, or the hypertonicity of a hypertensive gastro-œsophageal sphincter.

This immediately raises the question in one's mind whether these conditions are manifestations of the same disease or are separate entities. . The answer to this question we will defer till the case material has been described.

The subject matter of this article has been collected over a period of five years at the Thoracic Surgical Clinic, General Hospital, Colombo.

\section{Achalasia Cardia}

Although the disease has been known to exist over 30 years, Thomas Wallis of Oxford is credited with the first clear description; he treated it with bougies (quoted by Steichen, Heller and Ravitch, 1960). Over the passage of years the common clinical manifestations of this disease became associated with the classical picture of its occurence in the middle age-group of 20 to 40 with a slight female preponderance and often associated with an emotional tendency.

\section{The Role of Personality and the Disease}

Hoffman (1733) was the first to draw attention to the role of personality and the disease. $\mathrm{He}$ stressed the emotional aspect which predisposed to the syndrome of achalasia. He described it as being common among hypochondriacs and hysterical subjects. Purton (1821), Hannay (1833) and von Rokitansky (1842) associated the disease with trauma to the chest. Very often emotional shock has been urged as the exciting cause of the disease. We have not been particularly impressed by the role of anxiety states in the disease. Of 32 cases treated six were in children under 14 years; the youngest being 6 months old.

We could not discern in these children any abnormality as regards their psychological make-

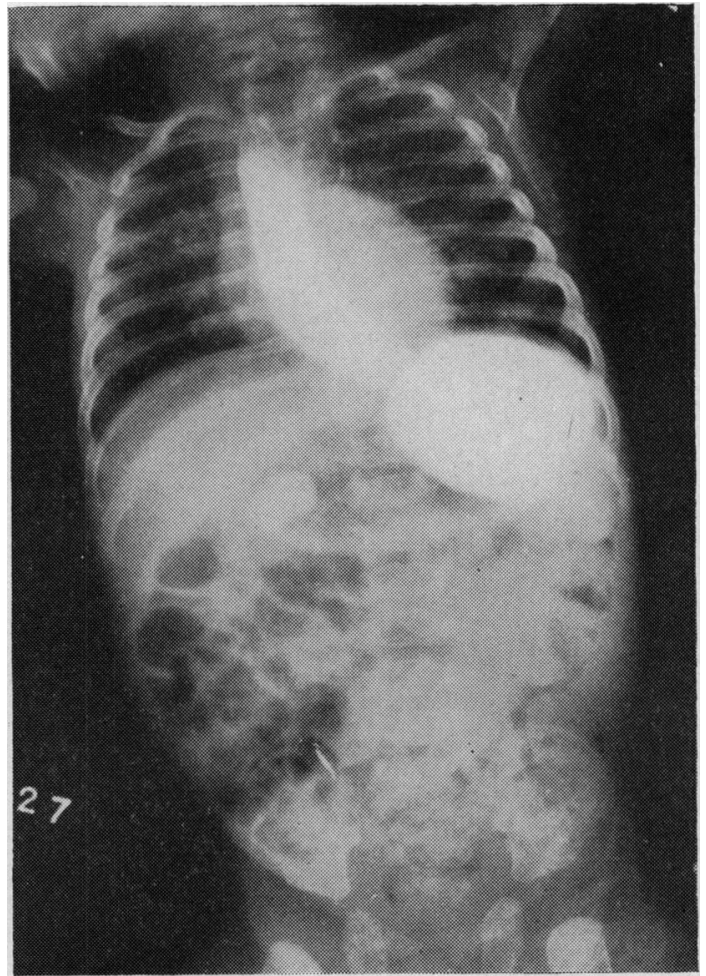

FIg. I.-Case No. I, showing achalasia in a six months old child.

up and it is difficult to believe that an infant 6 months old could have a psychological disturbance. Of the adults in this series only two gave a history of emotional upset as a predisposing cause of their illness. The majority of the adults were of stoic, staid type. None of these ascribed the disease to trauma.

\section{Case Report-I}

A female, aged six months, was referred from the Children's Hospital on 24.I 1.58 with a history of vomiting after meals. This was accentuated unless the child was fed in the sitting position. There was a 
previous history of repeated gastro-enteritis and bronchitis. On examination the child was emaciated and under-weight $\left(5 \frac{1}{2} \mathrm{lb}\right.$.). She had a temperature of $102{ }^{\circ} \mathrm{F}$. and pulse rate of $120 / \mathrm{min}$. There were crepitations in the bases of both lungs. The abdomen was distended but soft. Radiological examination showed collapse and consolidation of the right middle lobe and the lateral segment of the right upper lobe with bronchiolitic changes at both bases. X-ray after barium swallow showed appearances suggestive of cardiospasm (Fig. I).

Esophagoscopy was done and showed no organic obstruction. Heller's operation was done on 19.5.59 under general anæsthesia. At operation the œsophagus was moderately enlarged. The longitudinal and circular muscular fibres of the lower end of the œesophagus were markedly thickened with well-defined planes of cleavage.

Post-operatively the patient had abdominal distention which responded to calcium pantothenate, pituitrin and gastric suction. Post-operative $\mathrm{X}$-rays showed a general dilatation of the whole gastro-intestinal tract with neuromuscular incoordination of the rectum.

One year later the patient, on review, was free of symptoms.

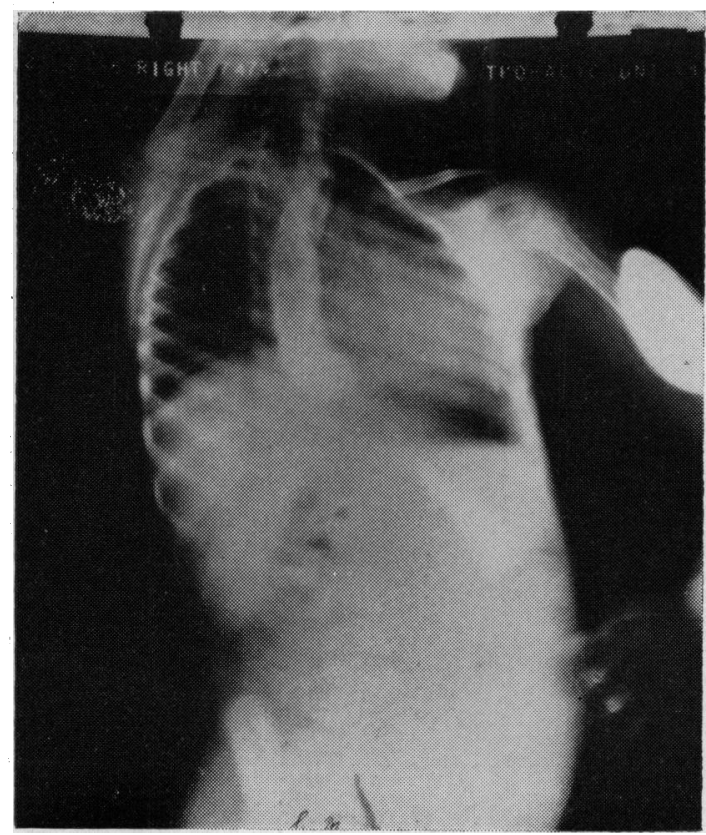

FIG. 2.-Case No. 2, showing a moderately dilated cesophagus in a child.

\section{Case Report-2}

Female, age two years nine months, admitted on 26.6.54 with a history of regurgitation of food of two years' duration. For the first nine months after birth there was no regurgitation of food. When the child was weaned and rice introduced in the diet, regurgitation was noticed. The regurgitation had been progressive over the subsequent two years. The regurgitation occurred five minutes after a meal. Swallowing water between mouthfuls of food diminished the regurgitation. Barium swallow showed a moderately dilated œsophagus (Fig. 2).

Esophagoscopy showed a dilated cesophagus with superficial œsophagitis. The œsophagoscope passed easily into the stomach. She was treated with repeated dilatations. For the next year she was free of symptoms 3 Re-admitted in February 1956 with dysphagia and regurgitation of food. Radiological examination showed increased dilatation of the œsophagus with a hold-up at; the lower end.

Heller's operation was done on 9.3 .56 with relief of symptoms, except for a temporary recurrence of slight regurgitation seven months later which was relieved by dilatation.

\section{Comment}

Case 1 : We have been unable to trace any case of achalasia in the literature that was younger thanour patient (6 months). This was an undoubtedw case of achalasia, which was in a desperate condi $=\frac{\text { T }}{6}$ tion prior to surgery. It is interesting to note that the achalasia was associated with neuro-muscular. incoordination of the rectal region as shown on radiological examination and it would appear thate in this case the neuro-muscular dysfunction was generalized.

Case 2 is another example of achalasia in a very young child. This case was first seen clinically at the age of 2 years and 9 months, but the symptoms $\overrightarrow{C s}$ had been present at the age of 9 months. Surgical treatment became imperative at the age of 4 yearsi and 8 months. This case illustrates the two methods of treatment commonly practised dilatation of the œsophagus with a Negus bag $\underset{0}{0}$ Heller's operation (Heller, I9I4).

We have not been convinced of the efficacy ${ }_{\overrightarrow{0} f}$ dilatation as a final curative method of treatment. Lawrence and Shoesmith (1959), in reviewing the treatment of cardiospasm, state that the failure rate after Negus dilatation was $8.2 \%$.

Allison (1950) recommended dilatation except in $\stackrel{\mathbb{Q}}{\rightarrow}$ special groups. It is not possible to conceive thatö dilatation with a Negus bag could effectively split all the muscular fibres of the lower asophagus, Heller (1914) stressed the need for a complete myotomy and advocated a double incision for this? purpose. Recurrence after an incomplete opera-: tion is common, and is commoner with the 3 . abdominal approach than with the thoracic ap-i் proach where a longer and more complete myotomy is possible (Douglas and Nicholson, 1959). The myotomy to be effective should? extend from the upper $\frac{1}{2}$ in. of the stomach to the inferior pulmonary vein. We do not believe that this could be duplicated by any form of dilatation. $N$ The single long myotomy with complete division N of all muscle obviates the necessity for the double myotomy advocated by Heller (1914).

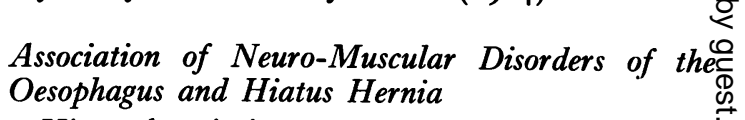

Hiatus hernia is not commonly associated with neuro-muscular disorders, Of the 32 cases, only $\overrightarrow{\mathbb{P}}_{\overrightarrow{0}}$ 


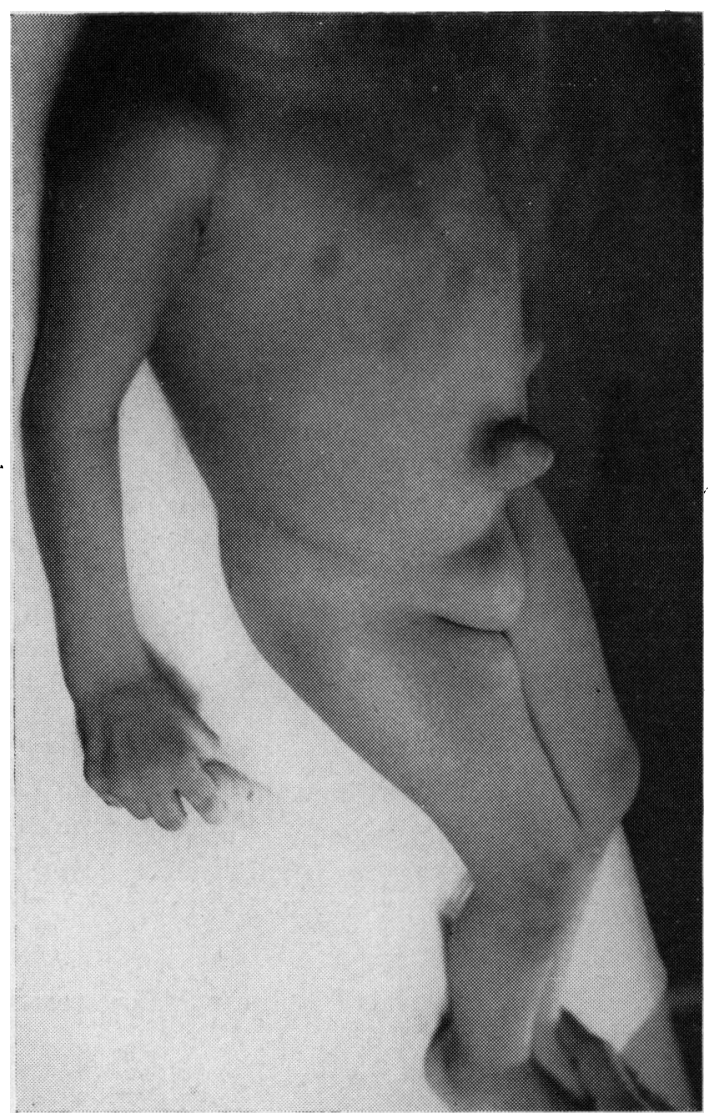

FIG. 3a.-Case No. 3, showing multiple herniæ.

one was associated with gross herniation of the stomach through the diaphragm. There were also multiple herniæ of the umbilical and inguinal regions in the same case.

\section{Case Report-3}

A female, aged three years, was admitted in September 1956. From the age of nine months she had regurgitation and vomiting of food, with frequent attacks of belching. Three months later umbilical and inguinal lumps appeared. The regurgitation and vomiting had been progressive over the subsequent two years. On examination there was severe emaciation. There were bilateral inguinal and umbilical herniæ which were reducible. There was a valgus deformity of the foot (Fig. 3a). Radiological examination showed a large para-œsophageal hiatus hernia of the stomach with a dilated cesophagus (Fig. 3b). The child was operated on on 17.9 .56 at which repair of the diaphragmatic hernia and Heller's operation were done. The inguinal and umbilical herniæ were repaired on 4.10.56. The post-operative course was uneventful except for temporary recurrence of symptoms eight months later which responded to dilatation. Review four and a half years later showed no recurrence of symptoms.

\section{Comment}

In this child multiple congenital defects were

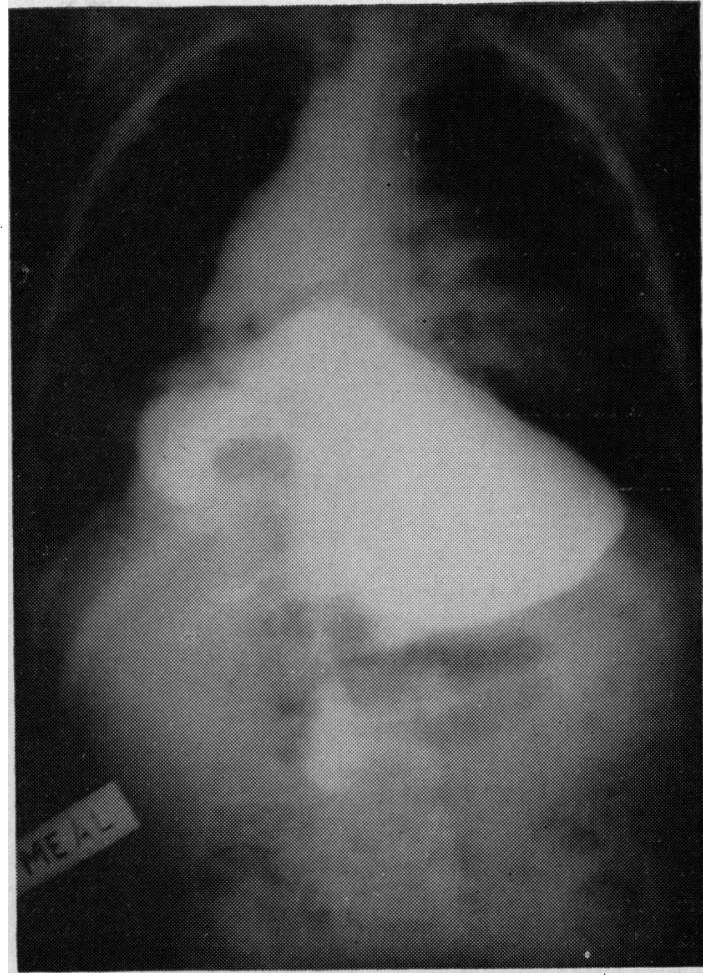

FIG. 3b.-Case No. 3, showing a large para-œsophageal hiatus hernia of the stomach and cardiospasm.

associated with achalasia cardia. It is interesting to speculate whether the achalasia was secondary to herniation of the stomach or a distinct entity of its own. There are three possibilities to consider. Firstly, whether the gross herniation of the stomach caused mechanical obstruction to the œsophagus. This is unlikely since no obstruction was demonstrated on œsophagoscopy. Secondly, whether the distortion of the stomach interfered with the function of the vagus nerves giving rise to secondary achalasia. This is unlikely as vagotomy only results in occasional temporary cardiospasm (Harris and Miller, 1960). Finally, the possibility is that this was true achalasia associated with multiple congenital defects. The operative findings and the response to surgery confirm this possibility.

Of the three cases of diffuse spasm of the œsophagus in our series, none was associated with hiatus hernia.

\section{The Musculature in Achalasia}

The distribution of the muscular thickening is not constant nor is it confined to any particular layer whether circular or longitudinal. Table 2 illustrates the distribution.

The friability of the muscle is variable; in the 
TABLE 2

Distribution of Muscular Thickening in 22 OPERATEd CASES

\begin{tabular}{l|c|c|c|c}
\hline $\begin{array}{l}\text { Distribution } \\
\text { of Muscular } \\
\text { 'I hickening } \\
\text { of the } \\
\text { Gsophagus }\end{array}$ & $\begin{array}{c}\text { Both } \\
\text { Layers }\end{array}$ & $\begin{array}{c}\text { Circular } \\
\text { Layer } \\
\text { Only }\end{array}$ & $\begin{array}{c}\text { Longi- } \\
\text { tudinal } \\
\text { Layer } \\
\text { Only }\end{array}$ & $\begin{array}{c}\text { Both } \\
\text { Layers } \\
\text { Atrophied }\end{array}$ \\
\hline Upper third & - & - & $I^{*}$ & - \\
\hline Middle third & $\mathbf{I}$ & $\mathrm{I}^{*}$ & - & - \\
\hline Lower third & 3 & - & - & - \\
\hline Diffuse & $\mathbf{I}$ & - & - & $\mathbf{I}$ \\
\hline
\end{tabular}

*Same case.

average case it is more friable than normal. In one of our cases of megaœsophagus the muscle actually ruptured while the cesophagus was being mobilized and very little surgery was necessary to convert it into a Heller's operation. In typical achalasia the tissue planes between the longitudinal and circular muscle become well defined and easily dissectable. This is in contrast to the normal œsophagus where the cleavage planes are not easily worked. This feature is so constant that in its absence we have had reason to question the diagnosis.

TABLE 3

Age/SeX InCidence

\begin{tabular}{|c|c|c|c|}
\hline \multirow{2}{*}{ Age in Years } & \multicolumn{2}{|c|}{ Sex } & \multirow{2}{*}{ Total } \\
\hline & Male & Female & \\
\hline $0-5$ & - & 3 & 3 \\
\hline $6-10$ & - & - & - \\
\hline $11-15$ & 3 & - & 3 \\
\hline $16-20$ & $\mathbf{I}$ & I & 2 \\
\hline $21-30$ & 4 & 2 & 6 \\
\hline $3 I-40$ & 2 & 6 & 8 \\
\hline $41-50$ & $\mathbf{I}$ & 2 & 3 \\
\hline $51-60$ & 3 & - & 3 \\
\hline $61-70$ & 2 & 2 & 4 \\
\hline Total & 16 & 16 & 32 \\
\hline
\end{tabular}

\section{Age and Sex Incidence}

This shows the unusual preponderance of children and young adults in this series. This is in contrast to the figures quoted by Douglas and Nicholson (1959) where the average age was 43 years and the youngest 21 years. The sex incidence is in accordance with other authors.
TABLE 4

Duration of Symptoms

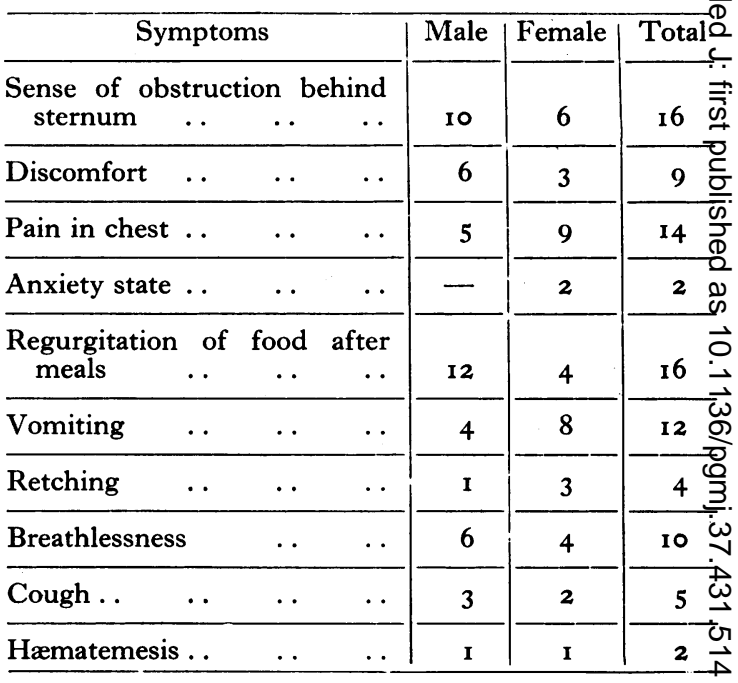

Symptomatology (See Table 4)

The commonest symptoms were regurgitations and a sense of obstruction. Pain was recorded iro I4 cases but was not severe and was not the presenting symptom.

\section{Diffuse Spasm of the Esophagus (Corkscre Csophagus)}

This condition was first described by Osgow ( 1889 ) and was more recently described as a clinica? entity in the American literature by Moersch ande Campbell (1934). There is a generalized increase of tone over the whole esophagus which is manio fest by violent peristaltic contractions visible on barium swallow. This may or may not be associated with hyperactivity of the sphincter zone Pain which is often intense and may mimic cardia e् pain is a predominating symptom in this group of neuromuscular disorders (Ellis, Code and Olsen? 1960). In our series of 32 cases only three cont formed to this type.

\section{Case Report-4}

A female, aged 65, admitted in December 1960. She complained of vomiting, weight loss, and loss of appetite of three years' duration. Esophagoscopy showed nos organic obstruction. Barium swallow showed a cork음 screw type of asophagus with delay of passage into the stomach (Fig. 4).

Heller's operation was done on 30.12.60. The circular muscle of the cesophagus was very thick and friable. Histologically the œsophageal muscle showed no change in Auerbach's plexus but there was an excess of fibrous tissue between the muscle layers. Post-operativo course was uneventful. Follow-up showed a diminutiof in calibre and vigour of peristaltic waves (Fig. 5).

\section{Comment}

In this condition, hyperactivity and spasticity are 


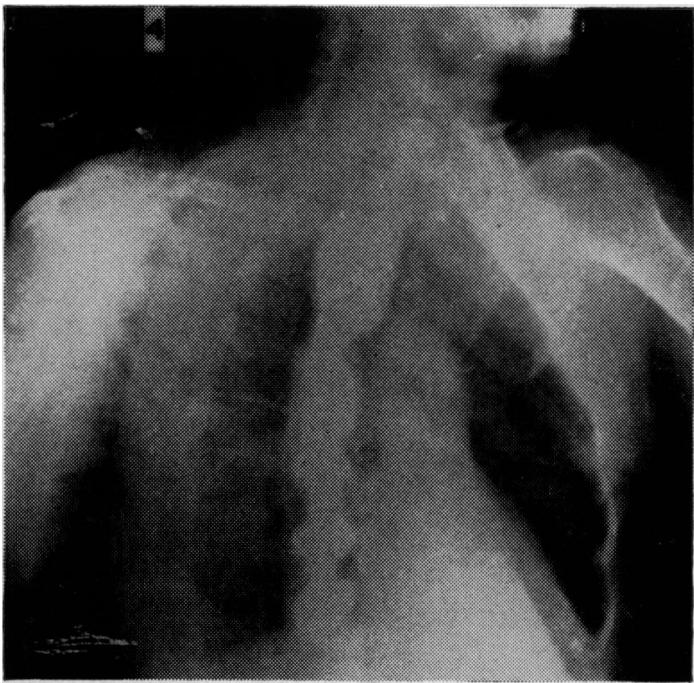

Fig. 4.-Case No. 4, showing a dilated corkscrew type of cesophagus (pre-operative).

contrasted with the motor failure and inactivity of classical achalasia. In the three cases in our series pain was not a prominent symptom. Treatment by medical means or dilatation is disappointing and strangely Heller's operation gives the best results. Is this condition a stage in the pathogenesis of achalasia or a separate entity ? Active peristaltic waves alone do not settle this question; we have seen a case of megacsophagus with

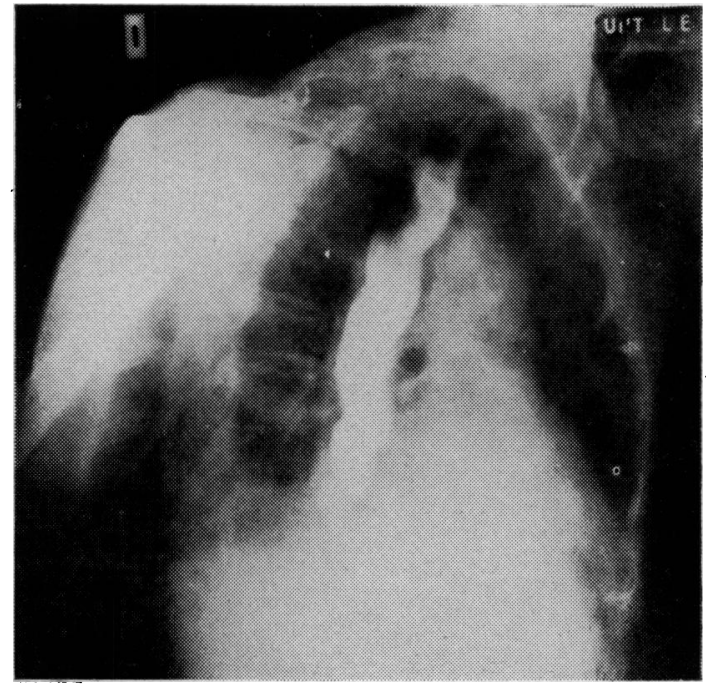

FIG. 5.-Case No. 4, showing œsophagus after operation.

active peristalsis (Fig. 7). Pain is not invariably present as shown in our series. The only differentiating point appears to be the widespread zone of increased intraluminal pressure.

\section{Megacesophagus}

Purton (1821) described the first case of megaœesophagus when the œsophagus formed a sac extending 2 in. below the pharynx to the cardiac

TABLE 5

Duration of Symptoms

\begin{tabular}{|c|c|c|c|c|c|c|c|c|c|}
\hline \multirow{2}{*}{$\begin{array}{l}\text { Duration of } \\
\text { Symptoms }\end{array}$} & \multicolumn{2}{|c|}{ Achalasia } & \multicolumn{2}{|c|}{ Megaœesophagus } & \multicolumn{2}{|c|}{ Diffuse Spasm } & \multicolumn{2}{|c|}{$\begin{array}{c}\text { Hypertrophic } \\
\text { Gastro-œsophageal } \\
\text { Sphincter }\end{array}$} & \multirow[t]{2}{*}{ Total } \\
\hline & Male & Female & Male & Female & Male & Female & Male & Female & \\
\hline -6 months & 5 & $\mathbf{I}$ & - & - & - & - & - & $\mathbf{I}$ & 7 \\
\hline 7 mths. - I year & - & - & - & - & - & - & - & $\mathbf{I}$ & $\mathbf{I}$ \\
\hline I year -2 years & 3 & 3 & - & $\mathbf{I}$ & $\mathbf{I}$ & - & - & - & 8 \\
\hline 2 years - 3 years & - & $\mathbf{I}$ & $\mathbf{I}$ & 2 & $\mathbf{I}$ & - & - & $\longrightarrow$ & 5 \\
\hline 3 years -4 years & - & - & 2 & - & - & $\mathbf{I}$ & - & - & 3 \\
\hline 4 years -5 years & - & $\mathbf{I}$ & - & - & - & - & - & - & $\mathbf{I}$ \\
\hline 5 years-10 years & - & 2 & - & - & - & - & - & - & 2 \\
\hline Io years-1 5 years & 2 & - & - & - & - & - & - & - & 2 \\
\hline if 5 years -20 years & - & - & 2 & - & - & - & - & - & 2 \\
\hline Not known & - & $\mathbf{I}$ & - & - & - & - & - & - & $\mathbf{I}$ \\
\hline & & & & & & & & Total & 32 \\
\hline
\end{tabular}




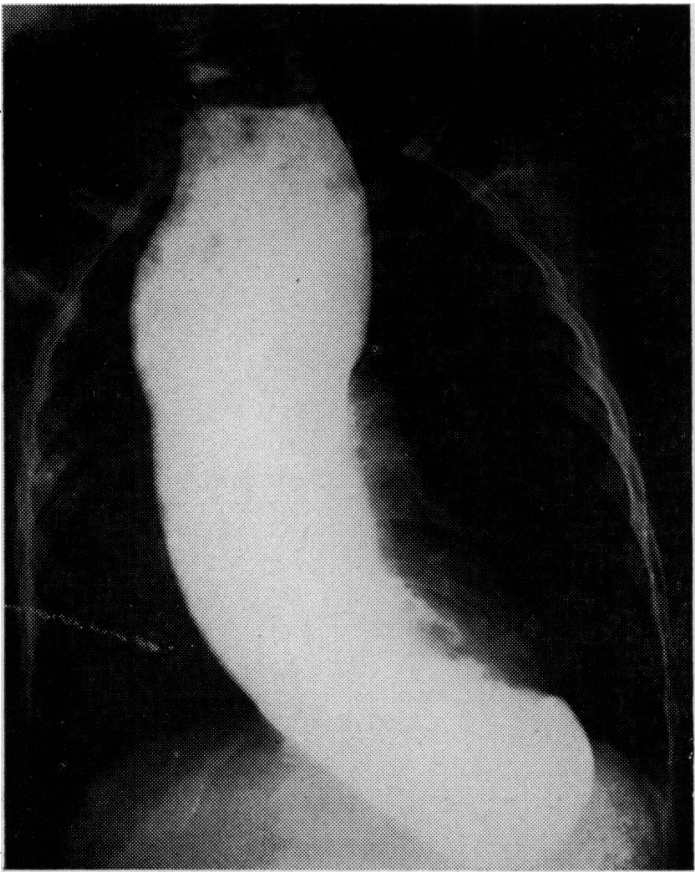

Fig. 6.-Megacesophagus.

orifice of the stomach. In this case the disease was of 20 years' duration and the patient ultimately died of inanition at the age of 43. The csophagus at autopsy contained two quarts of fluid.

In our series of 32 cases, eight cases were of megacesophagus where the dilatation was gross and extended from the pharynx to the cardia. Of these eight, four were in children aged 3, 4, I I and 13 years.

The duration of symptoms varied from one year three months to 20 years. The average duration was, however, about two years.

\section{Treatment}

The treatment of the grossly dilated and often ulcerated csophagus presents a formidable problem to the clinician. The inert sac contains a vast quantity of stagnant secretion that spills over into the lungs causing aspiration pneumonia (Fig. 6). Physiotherapy is essential to clear this complication. On the other hand there is great danger of sudden suffocation and drowning of the patient in his own secretions.

Theoretically, Heller's operation should not be successful in the treatment of megacsophagus but in practice it gives very good results. Contrary to expectations the dilated œsophagus may actually diminish in size. This occurred in two of our cases.

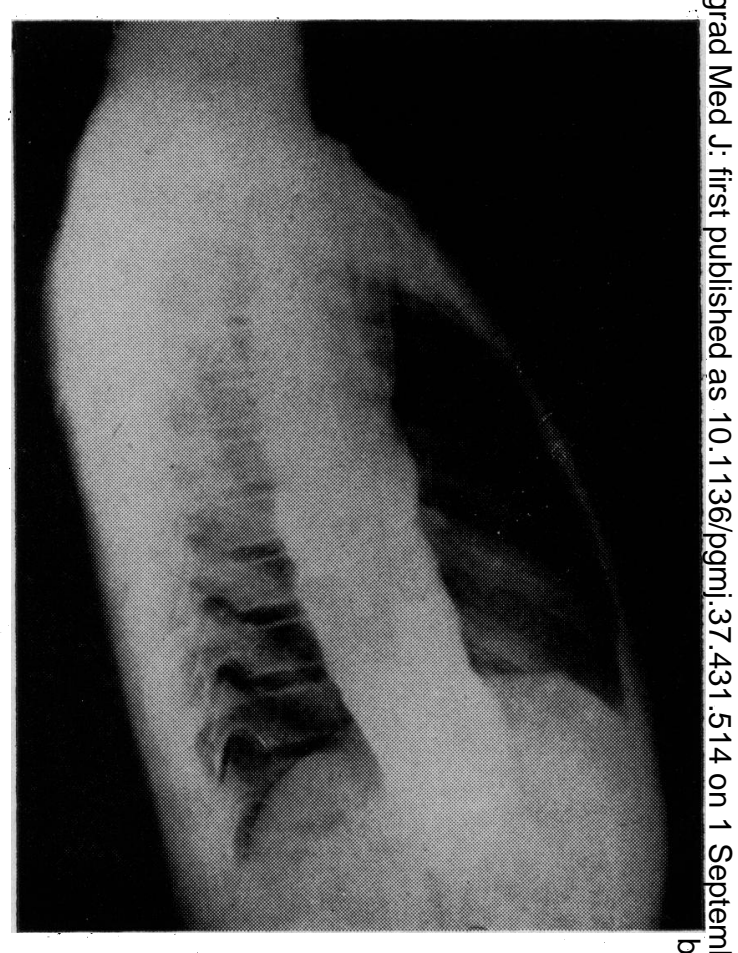

Fig. 7.-Case No. 5, showing the oesophagus, grosks dilated up to the pharynx with active peristafic waves involving the entire œsophagus.

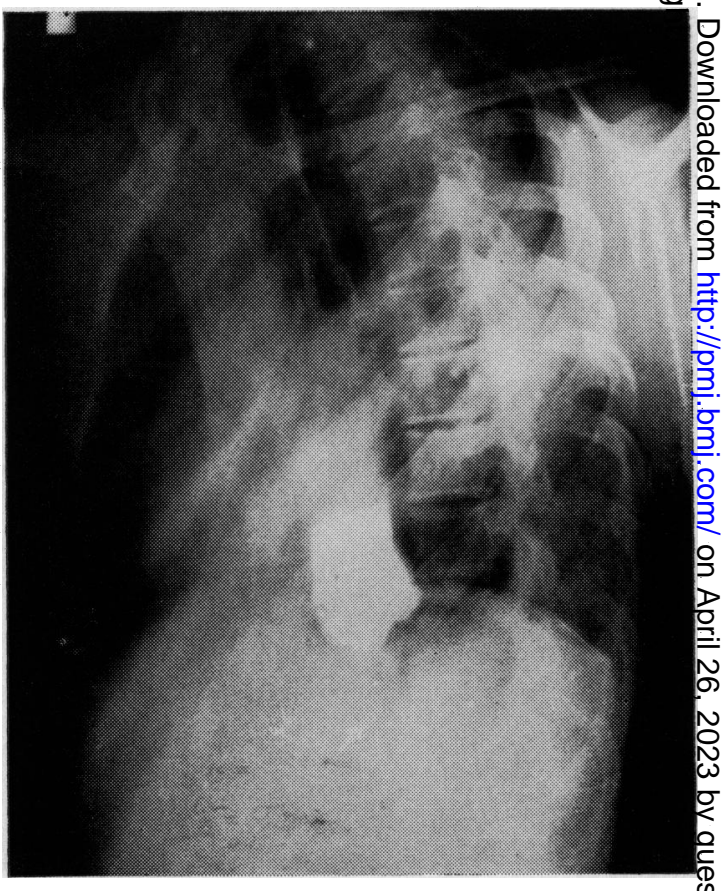

FIG. 8.-Case No. 5, three and a half years later, showing the decrease in size of the cesophagus. 


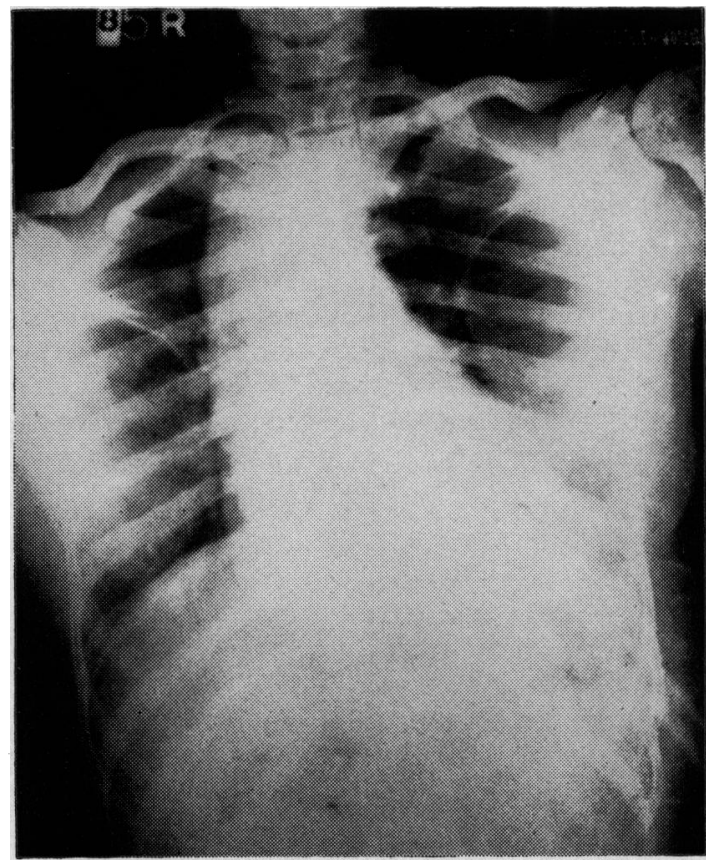

Fig. 9.-Case No. 6, showing a megacesophagus.

\section{Case Report-5}

A male, aged 13 years, was admitted in May 1957 with a history of dysphagia, cough and vomiting of three years' duration and dyspncea of one year's duration. The patient was well nourished. Esophagoscopy showed a dilated œesophagus with no stricture or ulceration. Radiologically the cesophagus was grossly dilated up to the level of the pharynx and showed active peristaltic waves of its whole extent. Heller's operation was done on 13.5.57. A post-operative leak of the cesophagus was noticed the next day which was due to necrosis of the mucosa following the use of diathermy to coagulate a blood vessel. This took several months to heal. Follow-up three and a half years later showed a marked diminution in size of the cesophagus with no symptoms (Figs. 7 and 8).

\section{Comment}

This reduction in size is remarkable as the radiological appearances post-operatively in the average case are disappointing although the patient is cured symptomatically. This aspect was first stressed by Heller. In another case (No. 6 ) the reduction in size was noticed one and a half months after operation (Figs. 9 and ro).

\section{Complications}

The dilated osophagus may accidently perforate during the performance of Heller's operation. In one of our cases the perforation was due to the use of diathermy to coagulate a bleeding point on the csophagus and the perforation was not noticed till the next day. - If the œsophagus is sigmoid in shape, the perforation may take a long

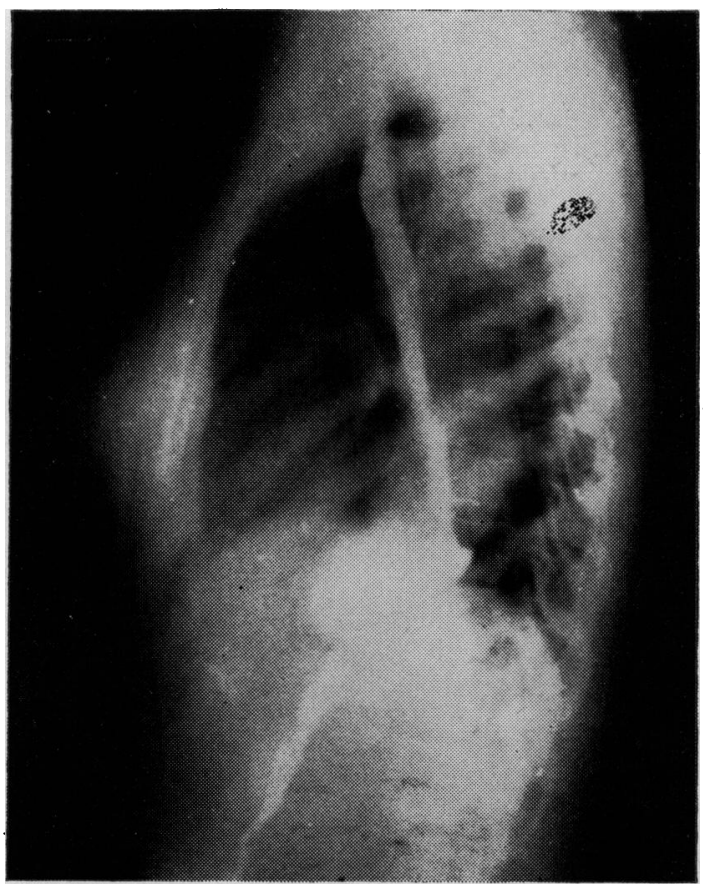

Fig. 10.-Case No. 6, one and a half months later, showing the decrease in size of the csophagus.

time to heal for obvious mechanical reasons. Ulceration of the dilated csophagus may cause severe bleeding, and was the cause of death in the only fatality in this series.

\section{Case Report-6}

A male, aged 53 years, was admitted on 29.6 .60 with a history of dysphagia for solids and liquids and regurgitation of food of 15 years' duration. He had excessive salivation and occasional pain on the right side of chest. He had to sleep propped up to prevent regurgitation of food. Esophagoscopy showed a grossly dilated and ulcerated œsophagus. In view of the grossly dilated and thinned-out osophageal wall, a pharyngo-jejunostomy was done. Post-operatively, severe uncontrollable bleeding occurred from the veins in the wall of the dilated cesophagus and the patient expired 48 hours after operation.

\section{Hypertensive Gastro-CEsophageal Sphincter}

This is a subdivision of recent origin which may manifest itself as a normal-sized œesophagus but with excessive spasm in the region of the sphincter as demonstrated by manometry. Two cases in our series fitted this category. One followed trauma.

\section{Case Report $\rightarrow 7$}

A female, aged 24 years, was admitted on 30.3.61 with a history of vomiting after meals of eight months' duration. Vomiting occurred 5-10 min. after the meal was eaten. The vomiting had increased gradually and on 
admission she used to vomit even fluids. She had no emotional disturbance. No pain in the chest. Her general condition was good. Radiological investigations showed a hold-up of barium at the lower end of the cesophagus with no dilatation. On œsophagoscopy no organic obstruction was seen but there was difficulty in passing the asophagoscope into the stomach due to spasm. Heller's operation was done on 7.4.61. The longitudinal muscle was easily resectable but the circular layer of muscles was not so well defined. There was a hypertensive gastro-œsophageal sphincter which was cut. On discharge the patient was free of symptoms.

\section{Conclusion}

The relationship between achalasia and megacsophagus is one of degree and this depends on a personal factor. All cases of achalasia do not necessarily progress to megacsophagus. The rate of development may be comparatively rapid and it may occur in young children.

The distinction in the spastic group of diseases between diffuse spasm and hypertensive gastrocesophageal sphincter is not justified merely on intraluminal pressure recordings. A change of motor pattern from week to week may occur in both conditions, for the disorder is not stable. Further, hypertensive gastro-œsophageal sphinc- ters may be associated with diffuse spasm sug gesting their common origin (Code, Schlegal Kelly, Jr., Olsen and Ellis, Jr., I960).

The relationship between the spastic group and achalasia is not so obvious. They differ basically in their pressure recordings. But in clinical? material it is possible to demonstrate cases that manifest both characteristics. Indeed, Code흠 Schlegal, Kelly, Jr., Olsen and Ellis, Jr. (1960) have been able to demonstrate a small proportiom of achalasia cases with spasticity of the sphincter We believe that achalasia and the spastic group aremanifestations of the same disease in pathogenesis:

\section{Summary}

I. The neuromuscular disorders of the œsophagus are discussed.

2. Cases of achalasia in early childhood are presented.

3. Varieties of achalasia are described.

4. The high rate of success of Heller's operations is due to the extensive and meticulous myotomy? done through the thoracic approach.

5. The possible pathogenesis is discussed.

\section{REFERENCES}

Allison, P. R. (1950): Treatment of the Achalasia of the Cardia, Proc. roy. Soc. Med., 43, 425.
Code, F. C., Schlegal, J. F., Kelly, M. L., Jr., Olsen, A. M., and Ellis, F. H., Jr. (1960): Hypertensive Gast œesophageal Sphincter, Proc. Mayo Clin., 35, 391.

Douglas, K., and Nicholson, F. (1959): The Late Results of Heller's Operation for Cardiospasm, Brit. F. Surf 47, 250.

Ellis, F. H., CoDE, C. F., and Olsen, A. (1960): Long CEsophagomyotomy for Diffuse Spasm of the CEsophagus and Hypertensive Gastro-Gssophageal Sphincter, Surgery, 48, 155.

Hannay, A. F. (1833): An Extraordinary Dilatation (with Hypertrophy) of all the Thoracic Portion of the Esophaguis causing Dysphagia, Edinb. med. Y., 40, 65.

HARRIS, J., and MilleR, C. M. (1960): Cardiospasm following Vagotomy, Surgery, 47, 568.

HeLleR, E. (1914): Extramukos Kardiaplastik beim Chronischen Kardiospasmus mit Dilatation des Esophagus Mitt. Grenzgeb. Med. Chir., 27, 141.

Hoffman, Fr. (1733): Dissertatio Inauguralis. Medica de Spasmis Gulae Inferioris et de Nausea.

INGELFINGER, F. J. (1960): The Physiologic Background of Heartburn, Esophagitis and Cardiospasm, Arch. intern Med., 136, 770.

Lawrence, K., and Shoesmith, J. H. (1959): Review of Treatment of Cardiospasm, Thorax, 14, 211.

voN Mikulicz, J. (1882): Ueber Gastrokopie und Oesophagoskopie mit Demonstrationam Lebenden, Verh. dtsch? Ges. Chir., Congress II, Sitzung 2, p. 30.

Mokrsch, H. J., and CAMpbell, J. D. (r934): Diffuse Spasm of the Lower Part of the CEsophagus, Ann. Otol. (St Louis), 43, 1165.

OsGood, H. (1889), quoted by Schmidt, H. W. (1939): Diffuse Spasm of the Lower Half of the Esophagus, Amer. $\mathcal{P}_{3}$ dig. Dis., 6, 693.

Purton, T. (1821): An Extraordinary Case of Distension of the CEsophagus, forming a Sac, extending from 2 in? below the Pharynx to the Cardiac Orifice of the Stomach, Med. Physiol. F. (Lond.), 46, 540.

von Rokitansky, C. (1842): Abnomitaten des Calibers Und der Dicke der Wandung, Handb. path. Anat., 2, 159. Steichen, F. M., Heller, E., and Ravitch, M. M. (1960): Achalasia of the Esophagus, Surgery, 47, 846. 